\title{
CONCEPTUAL READINGS INTO THE COLD WAR: TOWARDS TRANSNATIONAL APPROACHES FROM THE PERSPECTIVE OF LATIN AMERICAN STUDIES IN EASTERN AND WESTERN EUROPE
}

Leituras conceituais na Guerra Fria: rumo a abordagens transnacionais a partir da perspectiva dos estudos latino-americanos na Europa Oriental e Ocidental Lecturas conceptuales en la Guerra Fría: hacia enfoques transnacionales desde la perspectiva de los estudios latinoamericanos en Europa Oriental y Occidental

\author{
ALBERT MANKE, KATEŘINA BŘEZINOVÁ \\ AND LAURIN BLECHA
}




\begin{abstract}
This bibliographical and conceptual essay summarizes recent research in Cold War Studies in Europe and the Americas, especially on smaller states in historiographical studies. Against the background of an increasing connectedness and globalization of research about the Cold War, the authors highlight the importance of the full-scale integration of countries and regions of the 'Global South' into Cold War Studies. Critical readings of the newly available resources reveal the existence of important decentralizing perspectives resulting from Cold War entanglements of the 'Global South' with the 'Global North.' As a result, the idea that these state actors from the former 'periphery' of the Cold War should be considered as passive recipients of superpower politics seems rather troubled. The evidence shows (at least partially) autonomous and active multiple actors.
\end{abstract}

KeYwORDs: new Cold War History; Global South; small States; Latin America; Europe.

\title{
RESUMO
}

Este ensaio bibliográfico e conceitual resume pesquisas recentes em Estudos da Guerra Fria na Europa e nas Américas, especialmente em pequenas potências, em estudos historiográficos. Num contexto de crescente ligação e globa lização da investigação sobre a Guerra Fria, os autores apontam a importância da integração em larga escala dos países e regiões do "Sul Global" nos Estudos da Guerra Fria. Leituras críticas dos recursos recém-disponíveis revelam a existência de importantes perspectivas de descentralização resultantes dos enredos da Guerra Fria do "Sul Global" com o "Norte Global". Como resultado, a noção de que esses atores estatais na antiga "periferia" da Guerra Fria serão considerados como receptores passivos da política das superpotências parece bastante problemática. A evidência mostra (pelo menos parcialmente) atores múltiplos e autônomos ativos.

PalaVras-CHAVE: nova História da Guerra Fria; Sul Global; pequena potência; América Latina; Europa.

\section{RESUMEN}

Este ensayo bibliográfico y conceptual resume investigaciones recientes sobre Estudios de la Guerra Fría en Europa y las Américas, especialmente sobre las pequeñas potencias, en estudios historiográficos. En el contexto de una conexión creciente y de la globalización de la investigación sobre la Guerra Fría, los autores señalan la importancia de la integración a gran escala de países y regiones del "Sur Global" en Estudios de Guerra Fría. Las lecturas críticas de los nuevos recursos disponibles revelan la existencia de importantes perspectivas de descentralización resultantes de los enredos de la Guerra Fría del "Sur Global" con el "Norte Global". Como resultado, la idea de que estos actores estatales en la antigua "periferia" de la Guerra Fría se consideren receptores pasivos de la política de las superpotencias parece bastante problemática. La evidencia muestra (al menos parcialmente) actores múltiples autónomos y activos.

Palabras Clave: nueva Historia de la Guerra Fría; Sur Global; pequeña potencia; América Latina; Europa. 
esearch on the Cold War has long concentrated on key confrontations between

the superpowers (Autio-Sarasmo \& Humphreys, 2010a: 16). Since the end of the millennium, however, there has been increasing interest in actors and issues previously overlooked in the bipolar perspective. Last decade was especially prolific in introducing debates coined by postcolonial and subaltern approaches to the development of countries and societies in the 'Global South' - a term usually used by Cold War scholars to designate the states formerly referred to as belonging to the 'Third World.' ${ }^{1}$ Robert McMahon describes this as follows: "The upsurge of interest in such 'hot' topics as decolonization, development, sovereignty, state-formation, and human rights has helped move the Third World from periphery to center stage in several disciplines and subfields, fueling a burgeoning scholarship on the global South during the postwar era" (McMahon, 2013: 4).

According to Rupprecht, this growing interest is the result of a changed perspective: "Meant as a conscious delimitation of Eurocentrism, the focus is being redirected to the places where the Cold War was hot and where its consequences can be observed in the clearest fashion until today: to the Third World"2 (Rupprecht, 2007:2). McMahon (2005) and Jacob (2015a: 5) also have contributed to Rupprecht's argument. Moreover, since most Cold War conflicts were staged in the 'Global South,' it is only partially appropriate to term these places as the 'periphery' (Jacob, 2015). ${ }^{3}$ Interactions between local endeavors of decolonization and the influence of the superpowers (Bradley, 2010; Engerman, 2011), as well as postcolonial (Kwon, 2010), transnational, and transsystemic (Péteri, 2008) perspectives are highlighted in other works that are part of this paradigm. Interpretations originating in other world regions have also become more prominent (Hong, Szonyi \& Zheng, 2010). Studies of this kind can be grouped under the label New Cold War History. Building upon the first, innovative but still mostly bi-polar and elite-centered approaches by John L. Gaddis (1997; 2005), this new Global History research of the Cold War was fundamentally articulated by Odd Arne Westad's seminal monograph The Global Cold War (2005).

This new line of research was enriched by approaches from cultural studies laying the foundation for real inter- and transdisciplinary dialogue. As McMahon notes: " [...] the cultural turn in the humanities and social sciences, with its insistence on the critical importance of race, gender, identity, religion, emotion, and language has also proved to be a powerful spur 
for Third World-oriented scholarship [...]" (McMahon, 2013: 4). By opening the way for an analysis of intersecting areas, the Cold War is increasingly being understood as a globally interwoven space and period of conflict (Maguire, 2016; Iber, 2015; Aparicio [et al.], 2013; Calandra \& Franco, 2012; Isaac/Bell, 2012; Niño Rodríguez \& Montero, 2012; Gienow-Hecht, 2010; Jervis, 2010; Greiner [et al.], 2009; Stöver, 2007: 247-296; Caute, 2003; Richmond, 2003). But it allows also for readings of social, economic, and cultural change (Immerman \& Goedde, 2013), and new approaches towards the conceptions of ideologies (Leffler, 2007). In order to include concepts other than just power struggles, Heymann and Martin-Nielsen speak of the Cold War as a "global condition affecting the whole world, not only the power blocs" (2013: 221). ${ }^{4}$

The fall of the Berlin Wall gave a new impulse to research on the Cold War with the opening of archives, especially in the former Soviet Union and its neighbors. Findings in Central and Eastern Europe, as well as the declassification of documents in the United States, Western Europe, China and Latin America provided further important insights into Cold War history that challenged some formerly accepted interpretations. (Bayerlein, 2016; Joseph, 2008: 8-9; Blanton, 2008; Spenser, 2008: 392-394; Hanhimäki \& Westad, 2004). This opening was at times accompanied by translations of documents into English, for instance by the Cold War International History Project (CWIHP) at the Woodrow Wilson International Center for Scholars in Washington. ${ }^{5}$ Some of such findings have been obtained through cooperation between Eastern and Western scholars (e.g. Fursenko \& Naftali, 2006). Since 2011 a committee of historians in Germany, that also has a section on Latin America, have been declassifying and analyzing Bundesnachrichtendienst (Federal Intelligence Service) documents from between 1945 and $1968 .{ }^{6}$

As a result, the Cold War is no longer primarily an area of American and Soviet/Russian historical memory and the related historiographies. Looking behind the 'Iron Curtain' (e.g. in Kramer \& Smetana, 2013; Vázquez Cienfuegos, 2015 and 2016), as well as multipolar and decentralized approaches allows us now to make the complexity of this conflictual period more tangible (Pieper Mooney \& Lanza, 2013).

Latin America's role in the global Cold War has usually been told as an intrinsic part of the history of the Americas. Here the longue durée story of the relationship between the different Latin American states and the United States since the rise of the U.S. to a hemispheric hegemonic power in the late $19^{\text {th }}$ century has occupied a prominent place (Pardo Rueda, 2014; Brands, 2010; Grandin \& Joseph, 2010; Joseph \& Spenser, 2008; O'Brien, 2007; Reid, 2007; McPherson, 2006; Nieto, 2003; Robinson, 2003; Ayerbe, 2001; Dietrich, 2007; Meding, 2007; Spenser, 2004; Grandin, 2002 and the collection of documents in Holden \& Zolov, 2000). In 
this context, the role of the United States as an imperialist aggressor and supporter of state terrorism has been highlighted (Grandin, 2004; Streeter, 2000; Rodríguez Cruz, 2005; Manke, 2014; Kornbluh, 2003; Harmer, 2011; Haslam, 2005; Menjívar \& Rodriguez, 2005; Lynch, 2011; Gill, 2004; Calloni, 2010; McSherry, 2005; Wright, 2007; Walker \& Wade, [2017]).7 The concern with the violations of human rights that accompanied U.S. involvement in Latin America during the Cold War has created a specific research area about the memories of the victims of Latin American dictatorships (see, amongst others, Luther [et al.], 2011; Mayer \& Molden, 2009; Molden, 2007). New research on Latin America in the Cold War, as shown in Joseph and Spencer (2008), goes a step further by focusing on the interactions between Latin American States and non-state actors.

Significantly fewer studies have examined the influence of the Soviet Union and other socialist states on Latin America during the Cold War (Rupprecht, 2015 and 2010; Andrew/ Mitrokhin, 2005: 27-137; Kanet, 2005; Paszyn, 2000). ${ }^{8}$ The exception is, of course, Cuba (Cabrera Arús, 2015; Loss, 2013; Loss/Prieto, 2012; Greiner, 2010; Diez Acosta, 2002). China's influence in Latin America during the Cold War was only marginally treated for many years. Its presence in the region has mostly been analyzed on a broader level and from a longer perspective (Manke, 2015; López, 2013: 221-236; Rothwell, 2013; García Triana, 2003; Mann, 2002). Because of the superpowers' central role both in the Cold War and in the production of knowledge, many 'Western' and 'Eastern' scholars remain bound to superpower paradigms and perspectives. Only a few of them envision other perspectives, such as South-South cooperation. For instance, Ribeiro (2015), Hatzky (2012) and Gleijeses (2002) have provided important insights into Cuba's engagement in Africa.

\section{THE 'COLD WAR': A VALID CONCEPT FOR A TRANSNATIONAL HISTORY OF EAST AND WEST?}

here already exist some studies which analyze societies in the two opposed ideological
blocs during the Cold War from a comparative perspective, e.g. in Eastern and Western Europe (Vowinckel, Payk \& Lindenberger, 2012). Vowinckel, Payk, and Lindenberger's analysis offers not only some new insights, but also a dialogue between different scientific cultures and traditions from diverse perspectives. The authors reckon that the very term 'Cold War' is in itself a Western imprint that was practically not in use in the 'Eastern Bloc' before 1989. They use it as an analytical term to stress complexity instead of unidimensional and undifferentiated explanations: "[...] instead of applying a schematic model to the changing realities of the Cold 
War, we want to explore its diverse horizons and multiple forms of expression - particularly in their European characteristics" (Vowinckel, Payk \& Lindenberger, 2012a: 1).

As a conceptual point of departure for a bibliographical analysis, the term 'Cold War' can be understood in the above-mentioned critically reflected sense, even without going as far as deconstructing the term in the sense of Wallerstein or Jacobs, as it seems as an operable basis for analyzing interactions between smaller states in this context. Wallerstein questions the universal validity of this term when he points to alternative models and movements, such as the Non-Aligned Movement (NAM). He argues that with the NAM a counter-narrative was constituted that cannot be subsumed under the concept 'Cold War' (2010: 17-18). Wallerstein misconceives here that the states which joined the NAM were not exempt from the effects of Cold War conflict. In the present context, one can follow Wallerstein's argument insofar as the concept 'Cold War' can be expanded through alternative readings that stem (albeit not exclusively) from the 'Global South.' Jacob uses Wallerstein's argument which relates in particular to Asia, and gives it validity for Africa, Latin America, and the Middle East to it (2015a: 5).

\section{SMALL STATES AND SECONDARY ACTORS IN LATIN AMERICA AND EUROPE DURING THE COLD WAR}

$M$ ore recent contributions have broached the issue of the relations and interactions between (Eastern and Western) Europe and Latin America, to go beyond the former obsession with the superpowers and broaden the scope of research (Manke \& Brezinová, 2016; Opatrný, 2010). The volume edited by Manke and Brezinová stands for the new trend that allows for decentralized and entangled readings of the Cold War. Although it does not offer a path-breaking study (as it represents mostly a translation of already published articles into German), by focusing on the interactions between small states and secondary actors on both sides of the Atlantic, the editors go beyond a merely bipolar perspective and enlarge it at the same time.

Similar kind of interactions, in this case between state and non-state actors and the media across ideological borders, were dealt with by the first edited volume of the Aleksanteri Cold War Series published by the Cold War Research Group at Helsinki University. According to the editors of this volume, interactions seem to be illustrated more easily if they take place between less powerful actors or states. Because we consider this a key element for framing the study of interactions between smaller states and actors in the Cold War, it is worth citing a long extract from these authors: 
As yet, these studies are almost exclusively 'top down,' focusing on high-level political decisionmaking and influential actors in the arena of the world politics. The new shift in research, which has shone light beneath the highest level decision-making at small and non-state actors, first emerged in the field of cultural studies but this development is now being strongly felt in the wider field of Cold War history. [...] These new Cold War studies focus on interaction and cooperation; individual states, non-state and small actors, including individuals on both sides of the Iron Curtain - with the special focus on the understudied Eastern point of view. Research has turned to ordinary people's encounters and interaction instead of confrontation a conflict (Autio-Sarasmo \& Humphreys, 2010a: 17).

We would like to go one step further and not only comparatively study the interactions between Eastern and Western states in Europe, but also analyze the states and actors in the 'Global North' and the 'Global South.' Some have carried out this kind of comparison through the (almost classical) lens of asymmetries, such as Tom Long who reflected on the relations between the United States and Latin America (2015: 1-3). By looking beyond, one can spotlight small states and secondary actors and highlight some of their interactions that rarely reflected a deep asymmetry. For a discussion of the concept of 'small states' from a political science perspective, see Maass (2009) and Belfer (2014). Small states can be defined in different ways, also in a relative sense, i.e., if their neighboring states are more powerful and limit their possible actions. The definition of small is challenging and often unclear (Hey, 2003: 2-3). Nevertheless, it is not just about observing small states' behavior inside their respective bloc, but also about the interactions between them that sometimes transcend ideological borders.

As some states do not meet the criteria of 'small states,' it seems useful to introduce the category 'secondary actors' which can mean regional powers (cf. Frazier \& Stewart-Ingersoll, 2012). The definition of 'secondary actors' can also include terms like 'middle states' or 'middle powers' (Von Bredow, 2003). Nevertheless, it seems to us as too static, since - depending on the regional or hemispheric context - a small state can develop into a regional or (temporarily) into a great power, as was the case of Cuba during its engagement in Angola (1975-1991). Not only states like Brazil and Argentina, but also a state like Cuba can be termed a 'secondary actor' in Latin America, if the circumstances allow such a categorization. In Europe, even Great Britain, a nuclear power, could be treated as a secondary actor in the Cold War if US interests were at stake (Cushion, 2016). But not only the relationship between Europe and the U.S. was marked by asymmetry, within Europe there also existed (and continue to exist) sharp contrasts: "The political complexity of Europe derives from the co-existence of a multitude of large and small states" (Heymann \& Martin-Nielsen, 2013: 230). 
By focusing on the relations between smaller states, they do not appear solely as extras in the superpowers' larger theaters during the Cold War (such as Cuba during the Cuban Missile Crisis). Researchers will be able to analyze more closely different forms of cooperation between these states and actors (such as international companies and scientific communities) and to sound out the potentials and constraints of such relationships. Furthermore, such an approach can provide fresh knowledge and new perspectives about the range in which smaller states were operating during that period. Research has shown that cooperation between smaller states frequently involved impulses from both directions, not just from Europe (Manke \& B̌̌ezinová, 2016: 18). Transnational, multilayered, and sometimes contradictory processes of entanglement can be observed which involved a whole range of actors and dynamics. Should we focus exclusively on conflicts, however, we would miss large part of the story: what we see are not only (more or less functioning) bilateral relations, but the circulation of people, ideas, technologies (Patti, 2015; Manke, 2015a; Bortlová, 2013), and cultural elements (Maguire, 2016; Cabrera Arús, 2015; Březinová, 2013).

Another rewarding approach can be found in the dialogue between 'Western' and 'Eastern' academic traditions. Researchers in Eastern, Central, and Western Europe have developed different interpretations of the Cold War as an academic subject, as well as scholars of different generations in their own field of expertise. By proceeding with this international, inter-systemic and intergenerational dialogue, we add yet another layer to interpretations that already have provoked quite contrary positions 'inside' Western traditions. This breaks up Western-centric ideas of a "clash of civilizations" (Huntington, 1996) and offers entangled visions of the 'other.'

These visions reveal two basic current tendencies. While among 'Western' scholars a critical analysis of the 'Western' hegemon (the United States) is becoming increasingly relevant (Joseph \& Spenser, 2008), 'Eastern' European scholars tend to embed their research in a general reappraisal of their countries' Cold War pasts. This can be seen as part of a revisionist process of coming to terms with their own past that helped to declassify thousands of documents of the period before 1989. While this transparency and self-criticism can be regarded in rather positive terms, it often comes with unilateral interpretations. The Soviet Union's politics concerning smaller states in its sphere of influence and even in relation to smaller states in Latin America is generally being condemned as negative. At the same time, the hegemonic influence of the United States on smaller states is interpreted in benevolent terms, even if some aberrations of its presumably benevolent dominance are acknowledged (Zourek, 2013). Although the negative impact of the Soviet Union is no longer being neglected among left-leaning 'Western' scholars, they usually limit it to the Soviet Union's European 'satellites' 
and continue to reject more conservative views of an overall negative interpretation of Soviet engagement. In the 'East,' revisionists have taken over most of the academic discourse, though new nationalist interpretations of their nation's communist past sometimes lead to a recovery of some elements that can show certain independence in decision-making from the Soviet Union. Some of the more reflective publications result from cooperation between scholars in the 'East' and 'West' (Maguire, 2016; Kramer \& Smetana, 2013).

Small states and secondary actors were usually bound to the influence of their respective hegemons and had only limited space for decision-making, both in Europe and in Latin America. But by looking at the interactions between these states, other layers and perspectives surface which seem to share more cooperative than conflictive characteristics. Still, the local or national narratives of each country, region or group have shaped their insertion in Cold War history in a decisive way, as have the different and entangled temporalities that have to be taken into account in order not to lose the local rootedness of transnational cooperation and conflict.

\section{CONCLUSIONS}

tates in the former 'periphery' of the Cold War cannot be considered merely as passive $\checkmark$ recipients of superpower politics in presumed 'centers,' but as (at least partially) autonomous and active actors. Their relationship with the superpowers often followed more pragmatic considerations than purely ideological ones. With this changed perspective, the competition of social orders invoked by David Skidmore takes a back seat in the discussion.

Furthermore, the great master narratives often shaped by bipolar bloc thinking can be expanded and partially questioned through these decentralizing interpretations of complex Cold War settings. This allows for the fact that Cold War Studies do not present themselves just as a field of international relations. Overlapping transdisciplinary approaches gain even more importance by enabling us to interpret and examine the global Cold War in new ways. This variety of research options opens up new approaches to the history of 'multiple modernities' invoked by Eisenstadt (2000) and Ortiz (2000) during the Cold War.

\section{Notes}

1 A critical discussion of these terms is offered by Dirlik (2007: 12-14).

2 This and all other citations were translated into English by the authors of the present bibliographical essay.

3 We are also aware of the contested nature of terms like the 'Third World', 'developing countries' or 'industrialized countries.' See also Englert, Grau, and Komlosy (2006:13). 
Albert Manke, KATEŘina BŘEzinOVÁ AND LAURin BlechA

4 For a deeper discussion of different definitions of the term 'Cold War' see Nehring (2012), Duara (2011), and Wallerstein (2010), amongst others.

5 Since 1991, the CWIHP has harbored an excellent open source digital archive on the global Cold War (http:// digitalarchive.wilsoncenter.org [2016-09-07]).

6 See http://www.uhk-bnd.de [2016-12-10].

7 Regarding the US imperialist role, the literature limits itself to allowing a short interruption during the Carter administration. See for instance Sikkink (2007: 121-147).

8 For an internal perspective of the Soviet Union during the Cold War see Zubok (2007).

\section{BIBLIOGRAPHY}

ANDREW, Christopher M. \& MITROKHIN, Vasilij N. The world was going our way: the KGB and the battle for the Third World. New York: Basic Books, 2005.

APARICIO, Fernando, GARCÍA FERREIRA, Roberto \& TERRA, Mercedes. Espionaje y politica: Guerra fría, inteligencia policial y anticomunismo en el sur de América Latina, 1947-1961. Montevideo: Ediciones B Uruguay, 2013.

AUTIO-SARASMO, Sari \& HUMPHREYS, Brendan (eds.). Winter kept us warm: Cold War interactions reconsidered. Jyväskylä: Bookwell Oy, 2010.

\& Introduction: Cold War interactions reconsidered. In: \& (2010), p. 16-22.

AYERBE, Luis Fernando. Los Estados Unidos y la América Latina: la construcción de la hegemonía. La Habana: Casa de las Américas, 2001.

BAYERLEIN, Bernhard H. Arquivos do comunismo e perspectivas de pesquisa 25 anos após a "Revolução dos Arquivos": um balanço global. Estudos Históricos, Rio de Janeiro, 29 (59), 2016, p. 787-812.

BELFER, Mitchell. Small state, dangerous region: a strategic assessment of Bahrain. Frankfurt am Main: Peter Lang, 2014.

BERNECKER, Walther L. et al. (ed.). Lateinamerika 1870-2000: Geschichte und Gesellschaft. Wien: Promedia, 2007.

BLANTON, Thomas S. Recovering the memory of the Cold War: forensic history and Latin America. In: Joseph \& Spenser (2008), p. 47-73.

BORTLOVÁ, Hana. Czech tractors, Cuban oranges: economic relations between socialist Czechoslovakia and revolutionary Cuba. CEJISS, Prague, 7 (3), 2013, p. 77-95.

BRADLEY, Mark. Decolonization, the global South and the Cold War, 1919-1962. In: LEFFLER \& WESTAD (2010), p. 464-485.

BRANDS, Hal. Latin America's Cold War. Cambridge \& London: Harvard University Press, 2010.

BŘEZINOVÁ, Kateřina. Turbines and weapons for Latin America: Czechoslovak documentary film propaganda in the Cold War context, 1948-1989. CEJISS, Prague, 7 (3), 2013, pp. 32-52. 
CABRERA ARÚS, María. Material socialism. Exhibition project. New York: The New School for Social Research, 2015.

Pioneros: building Cuba's socialist childhood. Exhibition Project. New York: The Sheila C. Johnson Design Center's Arnold and Sheila Aronson Galleries, 2015.

CALANDRA, Benedetta \& FRANCO, Marina (eds.). La guerra fría cultural en América Latina: desafíos y límites para una nueva mirada de las relaciones interamericanas. Buenos Aires: Biblos, 2012.

CALLONI, Stella. Operación Cóndor: pacto criminal. La Habana: Fondo Cultural del ALBA, 2006.

CAUTE, David. The dancer defects: the struggle for cultural supremacy during the Cold War. Oxford [et al.]: Oxford University Press, 2003.

CUSHION, Steve. "Profite" oder "Politik": Die Dilemmata der britisch-kubanischen Beziehungen zu Beginn des Kalten Krieges. In: MANKE \& BŘEZINOVÁ (2016), p. 105-126.

DIETRICH, Wolfgang. Von der Intervention zur Integration: Lateinamerika im Schatten der nordamerikanischen Hegemonialmacht und die politisch-militärische Rolle der USA im 20. Jahrhundert. In: BERNECKER et al. (2007), p. 153-170.

DIEZ ACOSTA, Tomás. October 1962: the 'missile' crisis as seen from Cuba. New York [et al.]: Pathfinder, 2002.

DINGES, John. The Condor years: how Pinochet and his allies brought terrorism to three continents. New York [et al.]: New Press, 2004.

DIRLIK, Arif. Global South: predicament and promise, The Global South, Bloomington, 1 (1), 2007, p. 12-23.

DUARA, Prasenjit. The Cold War as a historical period: an interpretive essay, Journal of Global History, Cambridge, 6 (3), 2011, p. 457-480.

EISENSTADT, Shmuel N. Die Vielfalt der Moderne. Weilerswist: Velbrueck, 2000.

ENGERMAN, David C. The Second World's Third World, Kritika: Explorations in Russian and Eurasian History, Washington, 12 (1), 2011, p. 183-211.

ENGLERT, Birgit, GRAU, Ingeborg \& KOMLOSY, Andrea. Globale Ungleichheit in historischer Perspektive. In: \&___ (eds.). Nord-Süd-Beziehungen: Kolonialismen und Ansätze zu ihrer Überwindung. Wien: Mandelbaum, 2006, p. 13-28.

FRAZIER, Derrick \& STEWART-INGERSOLL, Robert. Regional powers and security orders: a theoretical framework. London [et al.]: Routledge, 2012.

FUKUYAMA, Francis. The end of History and the last man. New York: Free Press, 1992.

FURSENKO, Aleksandr \& NAFTALI, Timothy J. Khrushchev's cold war: the inside story of an American adversary. New York \& London: Norton, 2006.

GADDIS, John L. We now know: rethinking Cold War history. Oxford [et al.]: Clarendon Press, 1997.

The Cold War: a new history. New York: Penguin, 2005. 
GARCÍA FERREIRA, Roberto (ed.). Guatemala y la Guerra Fría en América Latina, 1947-1977. Guatemala: Universidad de San Carlos de Guatemala, 2010.

GARCÍA TRIANA, Mauro. Los chinos de Cuba y los nexos entre las naciones. Vol. II. Boletín Problemas Filosóficos, La Habana: Sociedad Cubana de Estudios e Investigaciones Filosóficas, 2003.

GIENOW-HECHT, Jessica. Culture and the Cold War in Europe. In: LEFFLER \& WESTAD (2010), p. 398-419.

GILL, Leslie. The school of the Americas: military training and political violence in the Americas. Durham: Duke University Press, 2004.

GLEIJESES, Piero. Conflicting missions: Havana, Washington, and Africa 1959-1976. Chapel Hill [et al.]: The University of North Carolina Press, 2002.

GRANDIN, Greg. Off the beach. The United States, Latin America, and the Cold War. In: AGNEW, Jean-Christophe \& ROSENSWEIG, Roy (eds.). A companion to post-1945 America. New York: Blackwell, 2002, p. 426-445. Press, 2004.

The last colonial massacre: Latin America in the Cold War. Chicago [et al.]: University of Chicago

\& JOSEPH, Gilbert M. (eds.). A century of revolution: Insurgent and counterinsurgent violence during Latin America's long Cold War. Durham [et al.]: Duke University Press, 2010.

GREINER, Bernd. Die Kuba-Krise: Die Welt an der Schwelle zum Atomkrieg. München: C.H. Beck, 2010. 2009.

MÜLLER, Christian Th. \& WALTER, Dierk (eds.). Angst im Kalten Krieg. Hamburg: Hamburger Edition,

HANHIMÄKI, Jussi M. \& WESTAD, Odd A. (eds.). The Cold War: a history in documents and eyewitness accounts. New York [et al.]: Oxford University Press, 2004.

HARMER, Tanya. Allende's Chile and the inter-American Cold War. Chapel Hill: The University of North Carolina Press, 2011.

HASLAM, Jonathan. The Nixon administration and the death of Allende's Chile: a case of assisted suicide. London [et al.]: Verso, 2005.

HATZKY, Christine. Cubans in Angola: South-South cooperation and transfer of knowledge, 1976-1991. Madison: The University of Wisconsin Press, 2015.

HEY, Jeanne A. K.. Small states in world politics: Explaining foreign policy behavior. Boulder [et al.]: Lynne Rienner, 2003.

HEYMANN, Matthias \& MARTIN-NIELSEN, Janet. Introduction: perspectives on Cold War science in small European states, Centaurus, Aarhus, 55, 2013, p. 221-242.

HOLDEN, Robert H. \& ZOLOV, Eric (eds.). Latin America and the United States: a documentary history. Oxford \& New York: Oxford University Press, 2000.

HONG, Liu, SZONYI, Michael \& ZHENG, Yangwen (eds.). The Cold War in Asia: the battle for hearts and minds. Leiden \& Boston: Brill, 2010.

HUNTINGTON, Samuel P. The clash of civilizations and the remaking of world order. New York: Simon \& Schuster, 1996. 
IBER, Patrick. Neither peace nor freedom: the cultural Cold War in Latin America. Cambridge: Harvard University Press, 2015.

\& GOEDDE, Petra (eds.). The Oxford handbook of the Cold War. Oxford: Oxford University Press, 2013.

ISAAC, Joel \& BELL, Duncan (eds.). Uncertain empire: American history and the idea of the Cold War. Oxford [et al.]: Oxford University Press, 2012.

JACOB, Frank (ed.). Peripheries of the Cold War. Würzburg: Königshausen \& Neumann, 2015.

Introduction. In: JACOB (2015), p. 5-10.

JERVIS, Robert. Identity and the Cold War. In: LEFFLER \& WESTAD (2010), p. 22-43.

JOSEPH, Gilbert M. What we now know and should know: bringing Latin America more meaningfully into Cold War studies. In: JOSEPH \& SPENSER (2008), p. 3-46.

\& SPENSER, Daniela (Hg.) In from the cold. Latin America's new encounter with the Cold War. Durham: Duke University Press, 2008.

KANET, Roger E. Die sowjetische Unterstützung nationaler Befreiungskriege, Mitte/weg 36, Hamburg, 1, 2005, p. $22-42$.

KORNBLUH, Peter. The Pinochet file: a declassified dossier on atrocity and accountability. New York [et al.]: New Press, 2003.

KRAMER, Mark \& SMETANA, Vít (eds.). Imposing, maintaining, and tearing open the Iron Curtain: the Cold War and East-Central Europe, 1945-1989. Lanham [et al.]: Lexington Books, 2013.

KWON, Heonik. The other Cold War: New York: Cambridge University Press, 2010.

LEFFLER, Melvyn P. For the soul of mankind: the United States, the Soviet Union, and the Cold War. New York: Hill and Wang, 2007.

\& WESTAD, Odd A. (eds.). The Cambridge history of the Cold War. Vol. 2: Crises and détente. Cambridge: Cambridge University Press, 2010.

LONG, Tom. Latin America confronts the United States: asymmetry and influence. New York: Cambridge University Press, 2015.

LONGLEY, Kyle. In the eagle's shadow: the United States and Latin America. Wheeling: Harlan Davidson, 2002.

LÓPEZ, Kathleen. Chinese Cubans: a transnational history. Chapel Hill: The University of North Carolina PresS, 2013.

LOSS, Jacqueline. Dreaming in Russian: the Cuban Soviet imaginary. Austin: University of Texas Press, 2013.

\& PRIETO, José Manuel (eds.). Caviar with rum: Cuba-USSR and the post-Soviet experience. New York: Palgrave Macmillan, 2012.

LUTHER, Inga [et al.] (eds.). Erinnerung schreibt Geschichte: Lateinamerika und Europa im Kontext transnationaler Verflechtungen. Stuttgart: Heinz, 2011.

LYNCH, Edward A. The Cold War's last battlefield: Reagan, the Soviets and Central America. Albany: State University of New York Press, 2011. 
Albert Manke, KATEŘina BŘEzinOVÁ AND LAURin BlechA

MAASS, Matthias. The elusive definition of the small state, International Politics, London, 46 (1), 2009, p. 65-83.

MAGUIRE, Lori (ed.). The Cold War and entertainment television. Newcastle upon Tyne: Cambridge Scholars Publishing, 2016.

MANKE, Albert. El pueblo cubano en armas: Die Revolutionären Nationalmilizen und die Verteidigung der kubanischen Revolution von 1959. Stuttgart: Heinz, 2014.

. Chinese in the Cuban revolution: an ethnically marked political mobilization? In: UNIVERSITY OF COLOGNE FORUM 'ETHNICITY AS A POLITICAL RESOURCE' (ed.). Ethnicity as a political resource: conceptualizations across disciplines, regions, and periods, Bielefeld: Transcript, 2015, p. 237-252.

87-99.

Cuba y Checoslovaquia: una nueva alianza estratégica en la Guerra Fría. In: OPATRNÝ (2015), p.

\& BŘEZINOVÁ, Kateřina (eds.). Kleinstaaten und sekundäre Akteure im Kalten Krieg: Politische, wirtschaftliche, militärische und kulturelle Wechselbeziehungen zwischen Europa und Lateinamerika. Bielefeld: Transcript, 2016.

MANN, Stefanie. Discovery of a terra incognita: five decades of Chinese foreign policy towards Latin America. Mainz: Institut für Politikwissenschaft, Abteilung Politische Auslandsstudien und Entwicklungspolitik, 2002.

MAYER, David \& MOLDEN, Berthold (eds.). Vielstimmige Vergangenheiten: Geschichtspolitik in Lateinamerika, Wien \& Berlin: LIT, 2009.

McMAHON, Robert J. Heiße Kriege im Kalten Krieg: Überlegungen zu einem Paradox, Mitte/weg 36, Hamburg, 1, 2005, p. 5-21.

(ed.). The Cold War in the Third World. Oxford [et al.]: Oxford University Press, 2013.

MCPHERSON, Alan L. Intimate ties, bitter struggles. The United States and Latin America since 1945. Washington: Potomac Books, 2006.

MCSHERRY, J. Patrice. Predatory states: Operation Condor and covert war in Latin America. Lanham [et al.]: Rowman \& Littlefield, 2005.

MEDING, Holger M. Unausweichliche Konfrontationen: Die lateinamerikanische Staatenwelt und die USA. In: BERNECKER [et al.] (2007), p. 171-190.

MENJIVAR, Cecilia \& RODRÍGUEZ, Nestor (eds.). When states kill. Latin America, the U.S., and technologies of terror. Austin: University of Texas Press, 2005.

MOLDEN, Berthold. Geschichtspolitik und Demokratisierung in Guatemala: Historiographie, Nachkriegsjustiz und Entschädigung 1996-2005. Wien \& Berlin: LIT, 2007.

NEHRING, Holger. What was the Cold War? English Historical Review, Oxford, 77 (527), 2012, p. 920-949.

NIETO, Clara. Masters of war: Latin America and United States aggresssion from the Cuban revolution through the Clinton years. New York [et al.]: Seven Stories, 2003.

NIÑO RODRÍGUEZ, Antonio \& MONTERO, José Antonio (eds.). Guerra fría y propaganda: Estados Unidos y su cruzada cultural en Europa y América Latina. Madrid: Biblioteca Nueva, 2012. 
O'BRIEN, Thomas F. Making the Americas: the United States and Latin America from the age of revolutions to the era of globalization. Albuquerque: University of New Mexico Press, 2007.

OPATRNÝ, Josef (ed.). Las relaciones entre Europa Oriental y América Latina 1945-1989. (Ibero-Americana Pragensia, Supplementum 40) Praga: Universidad Carolina de Praga \& Editorial Karolinum, 2015.

ORTIZ, Renato. From incomplete modernity to world modernity. Daedalus, Cambridge (Mass.), 129 (1), 2000, Multiple Modernities, p. 249-260.

PARDO RUEDA, Rafael. Entre dos poderes: de cómo la guerra fría moldeó América Latina. Vol. 1. Bogota: Taurus, 2014.

PASZYN, Danuta. The Soviet attitude to political and social change in Central America, 1979-90: case-studies on Nicaragua, E/ Salvador and Guatemala. London [et al.]: Macmillan [et al.], 2000.

PATTI, Carlo. The origins of the Brazilian nuclear programme (1951-1955), Cold War History, London, 15 (3), 2015, p. 253-273.

PÉTERI, György (ed.). Nylon curtain: transnational and transsystemic tendencies in the cultural life of state-socialist Russia and East-Central Europe. Trondheim: Program on East European Cultures and Societies, 2006.

PIEPER MOONEY, Jadwiga E. \& LANZA, Fabio (eds.). De-centering Cold War history: local and global change. London \& New York: Routledge, 2013.

REID, Michael. Forgotten continent: the battle for Latin America's soul. New Haven [et al.]: Yale University Press, 2007.

RIBEIRO, Raquel. The Cubans in Angola (1975-1991): a cultural overview. In: JACOB (2015), p. 11-37.

RICHMOND, Yale. Cultural exchange \& the Cold War: raising the iron curtain. University Park: Pennsylvania State University Press, 2003.

ROBINSON, William I. Transnational conflicts: Central America, social change, and globalization. London [et al.]: Verso, 2003.

RODRÍGUEZ CRUZ, Juan Carlos. Girón, la batalla inevitable: la más colosal operación de la CIA contra Fidel Castro. La Habana: Capitán San Luis, 2005, 2 ${ }^{\text {nd }}$ ed.

ROTHWELL, Matthew D. Transpacific revolutionaries: the Chinese revolution in Latin America. New York: Routledge, 2013.

RUPPRECHT, Tobias. Progress - desarrollo - modernization: Konzepte von Fortschritt und Modernität in der geteilten sowjetisch-lateinamerikanischen Geschichte 1956-66, M.A. thesis. Universität Tübingen, 2007, online: http://tinyurl.com/zgby5ea.

Die sowjetische Gesellschaft in der Welt des Kalten Kriegs: Neue Forschungsperspektiven. Jahrbücher für Geschichte Osteuropas, Stuttgart, 58 (3), 2010, p. 381-399.

Soviet internationalism after Stalin: interaction and exchange between the USSR and Latin America during the Cold War. Cambridge: Cambridge University Press, 2015.

SIKKINK, Kathryn. U.S. human rights policy and Latin America. Ithaca [et al.]: Cornell University Press, 2007. 
ALbert MANKe, KATEŘina BřEzinOVÁ AND LAURin BlECHA

SPENSER, Daniela. Standing conventional Cold War history on its head. In: JOSEPH \& SPENSER (2008), p. 381-395.

(ed.). Espejos de la Guerra Fría. México, América Central y el Caribe. México: Porrúa, 2004.

STÖVER, Bernd. Der Kalte Krieg, 1947-1991: Geschichte eines radikalen Zeitalters. München: Beck, 2007.

STREETER, Stephen M. Managing the counterrevolution: the United States and Guatemala, 1954-1961. Athens: Ohio University Center for International Studies, 2000.

VÁZQUEZ CIENFUEGOS, Sigfrido. Los estudios checoslovacos sobre historia de América durante la Guerra Fría. In: Opatrný (2015), 223-236.

Guerra Fría e Historia: una aproximación a la historiografía iberoamericanista checoslovaca. In

Poder y conflictividad social en América Latina. Praga: Karolinum, 2016, p. 149-159.

VON BREDOW, Wilfried. Der rasante Aufstieg einer Mittelmacht. Kanadas Außenpolitik seit dem Zweiten Weltkrieg. In: VON BREDOW, Wilfried (ed.). Die Außenpolitik Kanadas. Wiesbaden: Westdeutscher Verlag, 2003, p. 13-36.

VOWINCKEL, Annette, PAYK, Marcus M. \& LINDENBERGER, Thomas (eds.). Cold War cultures: perspectives on Eastern and Western European societies. New York/Oxford: Berghahn Books, 2012. $1-20$.

European Cold War culture(s)? An introduction. In: VOWINCKEL, PAYK \& LINDENBERGER (2012), p.

WALKER, Thomas W. \& WADE, Christine J. Nicaragua: emerging from the shadow of the eagle. Boulder:Westview Press, [2017].

WALLERSTEIN, Immanuel. What Cold War in Asia? An interpretative essay. In: Hong, Szonyi \& Zheng (2010), p. 15-24.

WESTAD, Odd A. The global Cold War: Third World interventions and the making of our times. Cambridge [et al.]: Cambridge University Press, 2005.

WRIGHT, Thomas C. State terrorism in Latin America: Chile, Argentina, and international human rights. Lanham [et al.]: Rowman \& Littlefield, 2007.

ZOUREK, Michal. Political and economic relations between Czechoslovakia and the military regimes of the Southern Cone in 1970s and 1980s, CEJ/SS, Prague, 7 (3), 2013, p. 118-141.

ZUBOK, Vladislav M. A failed empire: the Soviet Union in the Cold War from Stalin to Gorbachev. Chapel Hill: The University of North Carolina Press, 2007. 